\title{
BIODEGRADATION OF TEXTILE DYES BASED ON WOOD CARRIERS
}

\author{
Jörgen Forss, \\ Ulrika Welander \\ Linnaeus university, Sweden
}

\begin{abstract}
Biodegradation of textile dyes from the azo class by Bjerkandera sp.and microbial consortium from forest residues. Bjerkandera's degradation ability was evaluated in unsterile environment and put out of competition from the microbial consortium inhabiting forest residues. Microorganisms from forest residues were evaluated and transferred to soft wood shavings with maintained biodegrade performance. A continuous system was created containing anaerobic and aerobic parts and a successful degradation was monitored by spectrophotometer and High pressure liquid chromatography (HPLC).
\end{abstract}

\section{KEYWORDS}

Continuous system, lignocellulosic material, HPLC, textile waste water treatment.

\section{INTRODUCTION}

Textile fibres are al construct by polymeric organic fibres, which can be synthetic, semisynthetic or natural fibre. Because of these different fibre types different dyes and processes have evolved to colour the material.

One of the most used dyes today is reactive azo dyes, which react chemically to the fibre and form a covalent bond between the dye molecule and the fibre. The dye molecule can also react with the alkaline ions in the solution; the hydrolysed dye which is formed is no longer capable of reacting with the fibre and so it must be washed out before dying is complete. [4] The drawback with reactive dyes is that $10-40 \%$ of the dyes never react with the fibre and the need or a wash-off step in the process. [5] Dye contents in waters treated in studies performed differs quite a bit, in the artificial waters from $20 \mathrm{mg} \mathrm{l}^{-1}$ to $2.5 \mathrm{~g} \mathrm{l}^{-1}$, while normally $10-50 \mathrm{mg}$ $1^{-1}$ is found in dye house effluents [11]. O'Neill [11] also states that a typical dye effluent from a textile mill contains several dyes.

Today the water demands and chemicals used in the process of forming textile fabrics is a rising environmental issue. In 2000 the EU production of fabrics represented $3.4 \%$ of the manufacturing industry's turnover and $6.9 \%$ of the industrial employment [5].

There are several methods to treat textile waste water. Treatment with different filters is very attractive since they open the opportunity to reuse water. The filters performance depends on parameters such as $\mathrm{pH}$ and concentrations. Filtration is divided into three categories: Ultrafiltration, nanofiltration and reverse osmosis. The membranes are constructed from several different polymer materials $[6,7]$. The drawback is that filter techniques demands high investment and operational cost. 
Dyes can also be degraded with oxidative processes that either use UV (Photodegradation) or combined with a catalyst and hydrogenperoxide $\left(\mathrm{H}_{2} \mathrm{O}_{2}\right)$ or ozone $\left(\mathrm{O}_{3}\right)$. Different catalysts are used as Co-ZSM-5, $\mathrm{Fe}_{2} \mathrm{O}_{3}, \mathrm{CdS}, \mathrm{ZnO}, \mathrm{WO}_{3}$, but most preferred is $\mathrm{TiO}_{2}$ [3]. Similar mechanism is also performed by electrochemical degradation methods, most well established is the Fenton process. However these methods demands investments and operational costs.

Biological processes can be performed by different living organisms; in sewage treatment bacteria and microscopic animal play important roles. Scientists from Environmental Protection Agency's (EPA's) Water Engineering Research Laboratory in Cincinnati, Ohio, studied the fate of water-soluble acid and direct dyes in the activated sludge process. 11 out of 18 textile dyes passed through the pilot-scale, activated sludge process untreated, 4 adsorbed onto the activated sludge and 3 underwent biodegradation.[12]

Anaerobic bacterial processes have proven able to degrade azo dyes, this probably due to the electrochemical unstable azo bond $(-\mathrm{N}=\mathrm{N}-)$, which can act as an electron receiver. The enzyme Azoreductase is used to donate electrons to the substrate (electron acceptor) $[2,16]$. However oxygen is a better electron acceptor and the azo bonds potential to receive electrons is reduced in the presence of oxygen $[14,16]$ Several bacteria have proven degradation activity and ability to produce the enzyme azoreductase. Investigations on intestinal bacterias have proven that species like Clostridium, Enterococcus and Bifidobacterium was able to split the azo dye direct blue 15 during anaerobic conditions. Alex [1] worked with a microbial consortium isolated from effluent water from Urafiki Textile factory and found that $0.3 \%$ glucose or $0.2 \%$ yeast extract to give the best enhancement in decolourization. Carbon can also be attained from lignocellulosic carrier material and if dye molecules are degraded aromatic amines become availably. The azo dyes can give rise metabolites, often aromatic amines, some of them even more toxic than the dye they origin from. [13] To decolourize water is just one part of the purification process; the next step is to mineralise the aromatic amines formed. Aromatic amines are smaller molecules which should be able to enter the bacterial cell to be mineralised on the inside. Several researchers have seen big decrease in toxicity from the effluent of the anaerobic step to effluent in the following aerobic step [10, 8]. Van der Zee and Villaverde [15] come in their review article to the conclusion that most aromatic amines are mineralised in the aerobic step.

Working with the aim to provide textile waste water treatment technology in developing countries it is important to keep operational and investment costs to a minimum.

\section{METHOD}

\subsection{Dyes}

\section{2}

Two of the most common azo dyes were used in this study, Reactive Red 2 and Reactive Black 5, molecular structure in figure 1. 

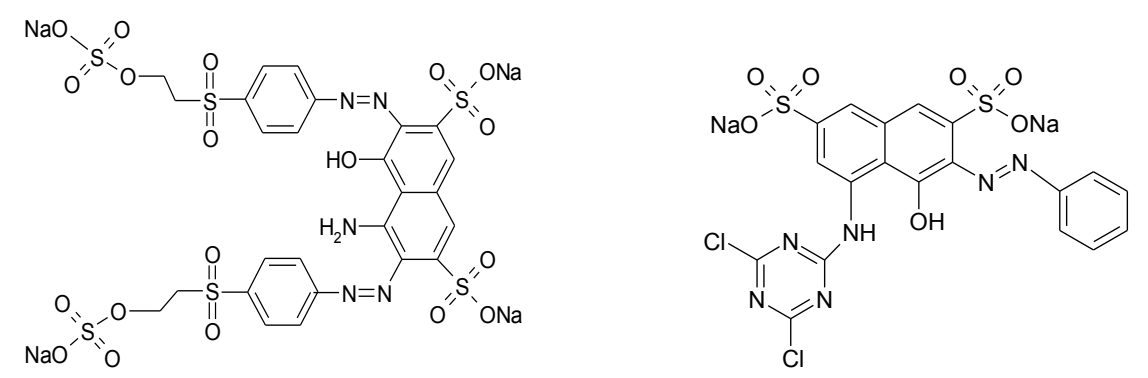

Figure 1: Molecule structure of Reactive Black 5 (left) and Reactive Red 2 (right)

\subsection{Fungus}

The first experiment was designed to use the White-root fungi Bjerkandera sp. Strain BOL-13 gene bank accession nr AY633927, which previous performed good degradation on both artificial waste water and real waste water from Urafiki textile industry in Dar es Salaam, Tanzania [9]. The fungus was inoculated on malt agar medium $\left(48 \mathrm{~g}^{-1}\right)$ in petri-dishes and incubated at room temperature. The media was autoclaved $15 \mathrm{~min}$ at $121^{\circ} \mathrm{C}$ prior to inoculation. In order to be cost efficient and sustainable, chips of forest residues were chosen as carrier to support growth of the fungus. The wood chips were inoculated by a $1 \mathrm{~cm}^{2}$ piece of malt agar overgrown with mycelia. The fungus was allowed to grow until it had been established on the wood chips. Bjerkandera was cultivated in unsterile environment and decolourization ability of $200 \mathrm{mg} \mathrm{l}^{-1}$ Reactive Red $2200 \mathrm{mg} \mathrm{l}^{-1}$ Reactive Black 5 with $1 \mathrm{~g} \mathrm{l}^{-1}$ of yeast extract was examined. Each experiment consisted of three replicates, with wood chips from forest residues as a carrier and substrate for the microorganisms. The experiments were designed with the composition shown in table 1. The flasks had the small plastic net installed in the middle of the $500 \mathrm{ml}$ E-flasks, see figure 4. In each flask $70 \mathrm{~g}$ of moisture forest residues wood chips, collected three days earlier from VEAB in Växjö, were put at one side of the net. To get the wood chips sterile, they were autoclaved $1 \times 99$ minutes at $135^{\circ} \mathrm{C}$ three consecutive days. The net and the flask are sterilised and all the pieces are put together in a sterile bench. The flasks were filled with $300 \mathrm{ml}$ of liquid, sterile water for the controls and sterile dye mix for the others, booth autoclaved for 15 minutes in the autoclave. Series $1_{\mathrm{A}}$, B \& $\mathrm{C}$ and $2_{\mathrm{A}}$, B \& $\mathrm{C}$ were inoculated by $1 \mathrm{~cm}^{3}$ of agar overgrown with mycelium of Bjerkandera $s p$. 
Table 1: Bach exp. 3 composition of carrier, micro organisms and artificial waste water.

\begin{tabular}{|c|c|c|c|c|c|c|}
\hline Batch & $\begin{array}{l}\text { Type of } \\
\text { chips }\end{array}$ & $\begin{array}{l}\text { Sterilis } \\
\text { ed }\end{array}$ & Bjerkandera & $\begin{array}{l}\text { Dye type } \\
200 \mathrm{mg} \mathrm{I}^{-1} \\
\text { of each dye }\end{array}$ & $\begin{array}{l}\text { Yeast } \\
\text { extract } \\
\left(\left.\lg \right|^{-1}\right)\end{array}$ & $\begin{array}{l}\text { Amount of } \\
\text { liq. (ml) }\end{array}$ \\
\hline $\begin{array}{l}\text { contr } \\
\text { ol }\end{array}$ & $\begin{array}{l}\text { Forest } \\
\text { residues }\end{array}$ & Yes & No & - & - & 300 \\
\hline $1 \mathrm{~A}$ & $\begin{array}{l}\text { Forest } \\
\text { residues }\end{array}$ & Yes & Yes & Red + black & Yes & 300 \\
\hline 1B & $\begin{array}{l}\text { Forest } \\
\text { residues }\end{array}$ & Yes & Yes & Red + black & Yes & 300 \\
\hline $1 \mathrm{C}$ & $\begin{array}{l}\text { Forest } \\
\text { residues }\end{array}$ & Yes & Yes & Red + black & Yes & 300 \\
\hline $2 \mathrm{~A}$ & $\begin{array}{l}\text { Forest } \\
\text { residues }\end{array}$ & No & Yes & Red + black & Yes & 300 \\
\hline 2B & $\begin{array}{l}\text { Forest } \\
\text { residues }\end{array}$ & No & Yes & Red + black & Yes & 300 \\
\hline $2 \mathrm{C}$ & $\begin{array}{l}\text { Forest } \\
\text { residues }\end{array}$ & No & Yes & Red + black & Yes & 300 \\
\hline $3 \mathrm{~A}$ & $\begin{array}{l}\text { Forest } \\
\text { residues }\end{array}$ & No & No & Red + black & Yes & 300 \\
\hline 3B & $\begin{array}{l}\text { Forest } \\
\text { residues }\end{array}$ & No & No & Red + black & Yes & 300 \\
\hline $3 \mathrm{C}$ & $\begin{array}{l}\text { Forest } \\
\text { residues }\end{array}$ & No & No & Red + black & Yes & 300 \\
\hline
\end{tabular}

\subsection{Transfer of microbial consortium}

To improve the analytical analysis the microflora from forest residues were transferred to soft wood shavings, three different ways of inoculation were tested. 1) The microflora were transferred by inoculate with three wood chips of forest residues without bark, which were chosen from three different places in the sack. 2) Approximately $100 \mathrm{~g}$ of forest residues wood chips in water with stirring during $1 / 2 \mathrm{~h}$ and then the water was separated by decantation, and had a dark brown colour from all the particles in it. 3) Batch H8 had wash water filtrated through filter munktell $\mathrm{nr} 3$, for experimental overview se table 2. 
Table 2: Series $H_{5-9}$ : Composition of carrier, micro organisms and artificial waste water

\begin{tabular}{|c|c|c|c|c|c|c|}
\hline Batch & $\begin{array}{l}\text { Wet } \\
\text { weight of } \\
\text { shavings } \\
\text { (g) }\end{array}$ & Sterilised & Treatment/inoculation & $\begin{array}{l}\text { Dye type } \\
200 \mathrm{mg} \mathrm{l}^{-1} \\
\text { of each } \\
\text { dye }\end{array}$ & $\begin{array}{l}\text { Yeast } \\
\text { extrac } \\
t \\
\left(1 \operatorname{g~l}^{-1}\right)\end{array}$ & $\begin{array}{l}\text { Amou } \\
\text { nt of } \\
\text { liq. } \\
\text { (ml) }\end{array}$ \\
\hline H5 & 39,1 & $\begin{array}{l}\text { Autoclaved: } \\
15 \text { min, } 220 \\
{ }^{\circ} \mathrm{C}\end{array}$ & - & $\begin{array}{l}\text { Red } \quad+ \\
\text { black }\end{array}$ & No & 350 \\
\hline H6 & 41,8 & No & 3 forest residues chips & $\begin{array}{l}\text { Red } \quad+ \\
\text { black }\end{array}$ & No & 250 \\
\hline $\mathrm{H} 7$ & 40,7 & No & $\begin{array}{l}20 \mathrm{ml} \text { forest residues wash } \\
\text { water }\end{array}$ & $\begin{array}{ll}\text { Red }+ \\
\text { black }\end{array}$ & No & 250 \\
\hline H8 & 43,4 & No & $\begin{array}{l}20 \mathrm{ml} \text { forest residues wash } \\
\text { water, filtrated }\end{array}$ & $\begin{array}{l}\text { Red }+ \\
\text { black }\end{array}$ & No & 250 \\
\hline H9 & 42,8 & $\begin{array}{l}\text { Autoclaved: } \\
99 \text { min, } 135 \\
{ }^{\circ} \mathrm{C}\end{array}$ & - & No & No & 250 \\
\hline
\end{tabular}

\subsection{Continuous system}

With the results from these studies above and literature review the continuous system in figure 2 was constructed. The continuous system was designed with two anaerobic reservoirs with a volume of $11 \mathrm{each}$, filled with approximately $100 \mathrm{~g}$ of soft wood shavings each (moist cont. 78-80\%). The third reactor was aerobic and had a volume of $500 \mathrm{ml}$ and $28 \mathrm{~g}$ of soft wood shavings (moist cont. $80 \%$ ). This reactor was aerated with compressed air through an air stone in the bottom.

The system was feed by artificial waste water composed of $200 \mathrm{mg} \mathrm{l}^{-1}$ Reactive Red $2200 \mathrm{mg}$ $1^{-1}$ Reactive Black 5 with $1 \mathrm{~g}^{-1}$ of yeast extract.

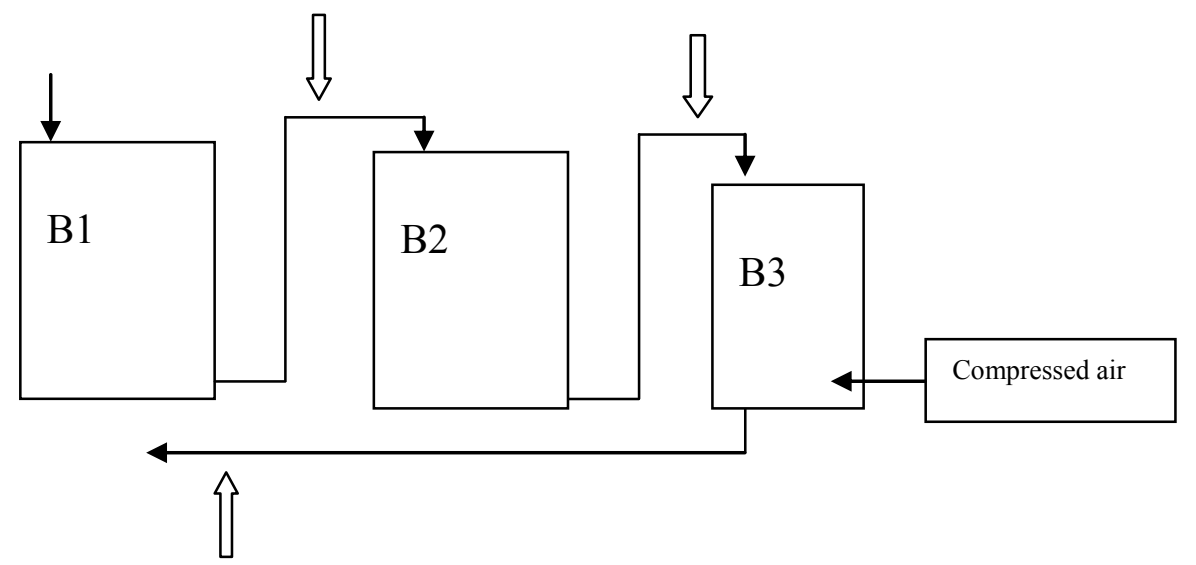

Figure 2: Continuous system

\subsection{Analysis}

Samples where filtered through a $0.45 \mu \mathrm{m}$ filter (Sartorius minisart). The samples were scanned in a spectrophotometer, Perking Elmer lambda 35 UV/VIS and analysed by Perkin 
Elmer UV winlab ver: 2.85 .04 software, from $190 \mathrm{~nm}$ to $750 \mathrm{~nm}$. The samples from the experiments were diluted 1:10 by taking $100 \mu \mathrm{l}$ sample, add $900 \mu 1$ of deionised water.

Some samples were analysed using the HP 1100 High pressure liquid chromatography (HPLC) system (Hewlett Packard, Waldbronn, Germany). The HPLC system was equipped with a G1314A deuterium lamp detector and a Fortis C18 $250 \times 4.6 \mathrm{~mm}, 3 \mu \mathrm{m}$ column (Dalco Chromtech, Sollentuna, Sweden), protected by a guard column containing the same packing material. The software used for processing and reporting data was ChemStation B.02.01 SR2 (Agilent Technologies, Santa Clara, CA, USA). The mobile phase was a gradient starting with $80 \% 50 \mathrm{mM}$ formic acid / $3.03 \mathrm{mM}$ Ammoniumformiat buffer (pH 2.8) (A) and 20\% methanol (B). The gradient increased linearly to $100 \%$ (B) and $0 \%$ (A) over $45 \mathrm{~min}$, and this condition was maintained for $5 \mathrm{~min}$; the post phase continued at $20 \%$ (B) and $80 \%$ (A) for 10 min. The detection was performed at $280 \mathrm{~nm}$.

\section{RESULTS AND DISCUSSION}

\subsection{Fungus}

An evaluation of the results from day 19; line 1 (sterile with Bjerkandera) performed $53 \%$, line 2 (unsterile with Bjerkandera) 59,6\% and line 3 (unsterile) 70,1\% decolourization. The fungus Bjerkandera did not perform as well as expected, but the microflora from forest residues proved interesting degradation ability. Wood has an interesting composition of cellulose, hemicellulose, pectin, lignin and resins that should support and evolve an interesting microflora with capacity to degrade variable molecular structures.

The experiment showed god decolourization visually and by spectrophotometer the first 20 days, but after day 23 absorbency increased again, probably due to substances released from the forest residues used as a supporting material (figure 4).

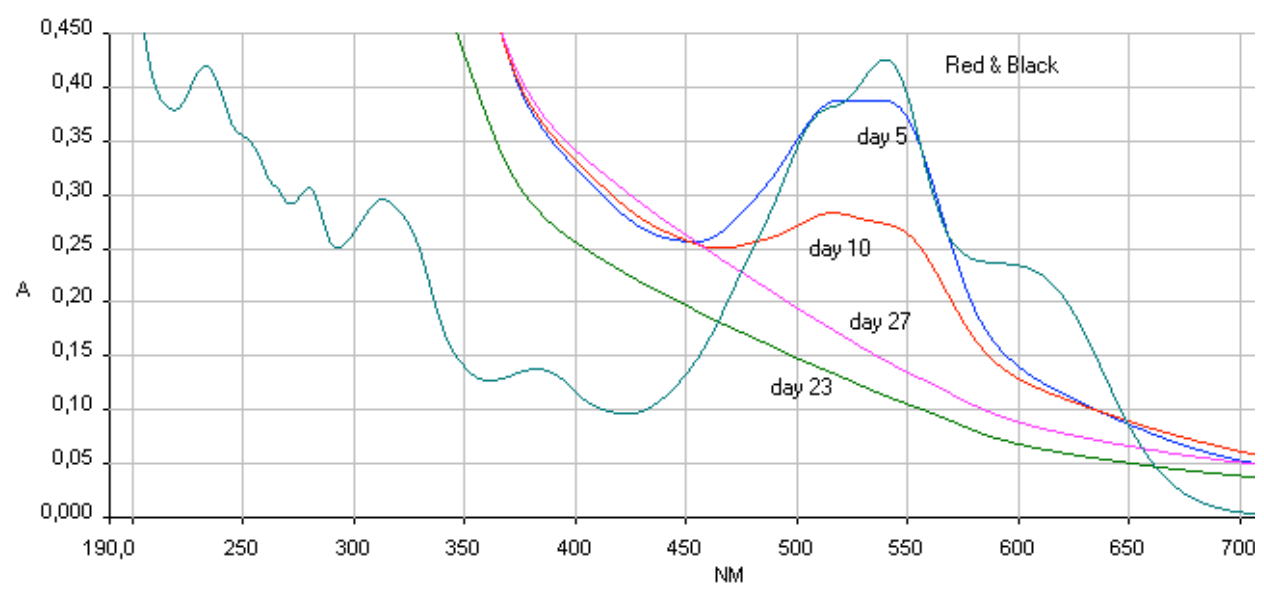

Figure 4: Absorbance series 3B unsterile F. res. chips, Bjerkandera sp. and yeast extract.

\subsection{Transfer of microbial consortium}

The three different way of inoculation seemed to al work well, with the best results for unfiltered rinse solution. After 16 days the decolourization was for H6 $75.4 \%$, H7 81.7 \%, H8 $71.8 \%$ at $550 \mathrm{~nm}$. Figure 5 show a visual example of the degradation in the H-series. The degradation continued further and after 43 days over $90 \%$ of the colour has disappeared. 


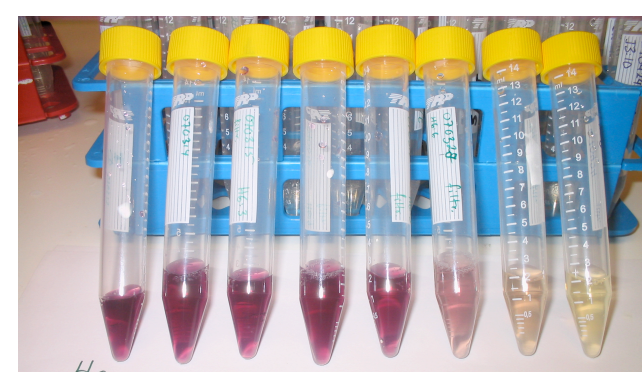

Figure 5: visual result of degradation H-series (H7), day 1 43.

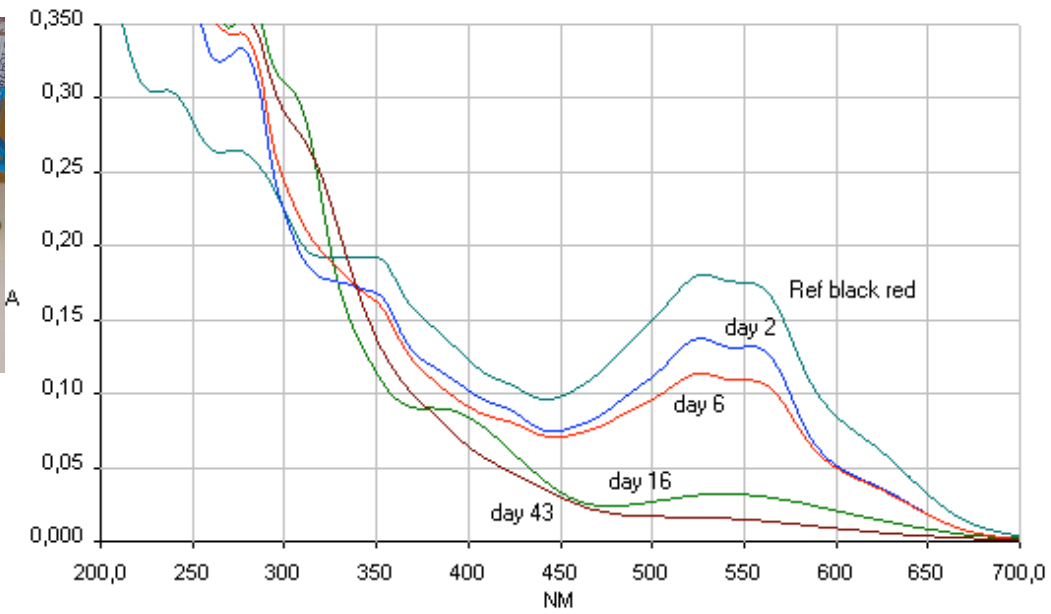

\subsection{Continuous system}

The continuous system was in use for 45 days, with a turnover rate at approximately 4 days and 20 hours each for the large reservoirs and 4 days 9 hour for reservoir three. The system had a total turnover rate of 14 days and 1 hour.

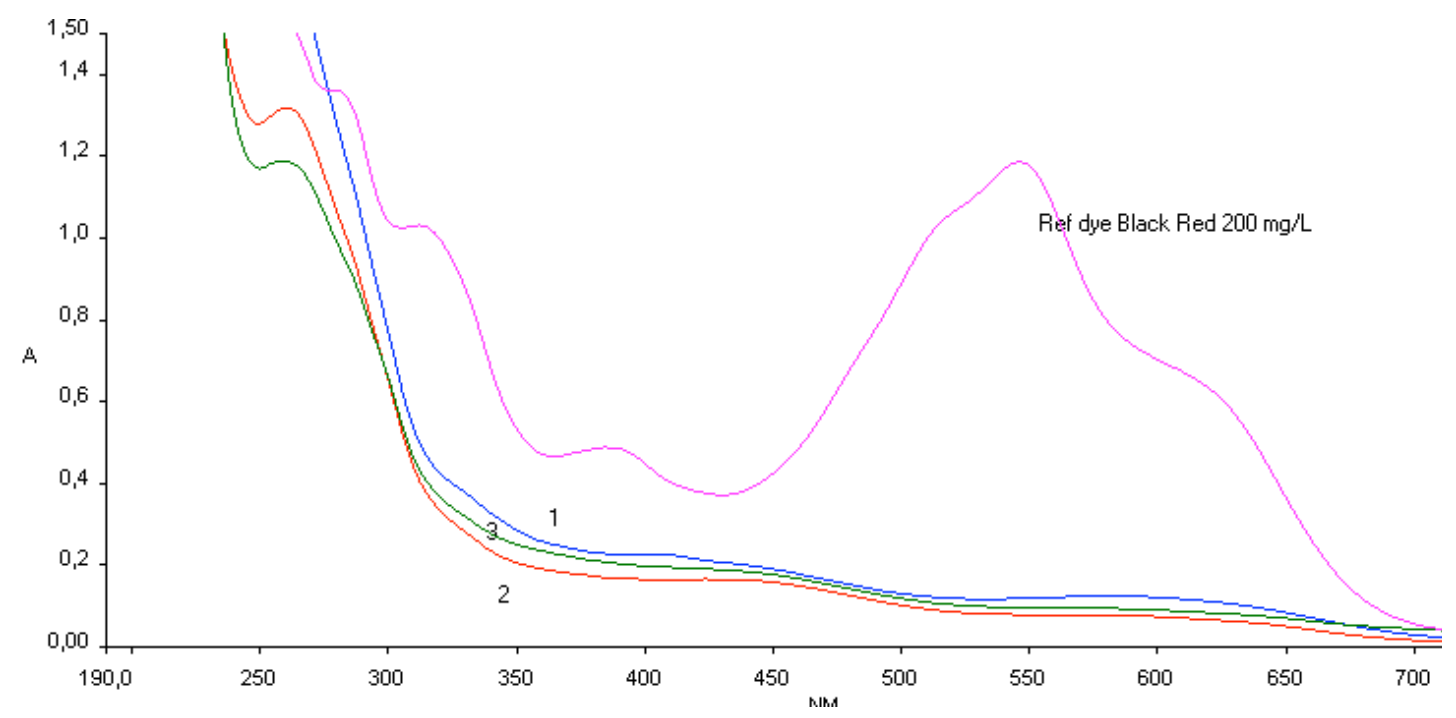

Figure 6: degradation in continuous system.

The graph in figure 6 shows clearly that the colour disappears in the first reservoir, probably due to breaking of azo bond. The decolourization at $550 \mathrm{~nm}$ was for reservoir $189.8 \%$, reservoir $293.3 \%$ and reservoir $391.9 \%$. However the fate of the metabolites is unclear.

The HPLC show that the dye molecules are degraded in reservoir 1, but also display metabolites, which was reduced in reservoir 2 and 3. Figure 7 a display the profiles for the two azo dyes, with major peaks at retention time (rt) 15.25 and 33.96. The HPLC diagram from outlet of reservoir 1 show no presence of the dyes profile, but a major peak at $\mathrm{rt} 3.79$ and several small peaks from $\mathrm{rt} 4-22$. In reservoir 2 (figure 7c) the peak at $\mathrm{rt} 3.79$ and several of the minor peaks from $\mathrm{rt}$ 7.6-22 have been reduced. From the third reservoir with aerobic environment, an increase of the peaks at $\mathrm{rt} 3.79$ and 14.75 and reduction of peaks at rt 4.2-6.8 is displayed. The continuous system efficient decolourized the artificial wastewater on merely 4 days (reservoir 1), the metabolites were tougher to metabolise, but was reduced by the 
further treatment in anaerobic and aerobic environment. Van der Zee and Villaverde [15] state in their article that an aerobic step after anaerobic degradation of azo dyes decrease the toxicity in the water, most aromatic amines are mineralised.

A system like this should be possible to implement at the ponds present at most textile mills today, especially since normal dye concentration in textile waste water is $10-50 \mathrm{mg}^{-1}$ [11]. 
Linnaeus ECO-TECH ' 10

Kalmar, Sweden, November 22-24, 2010

$7 a$

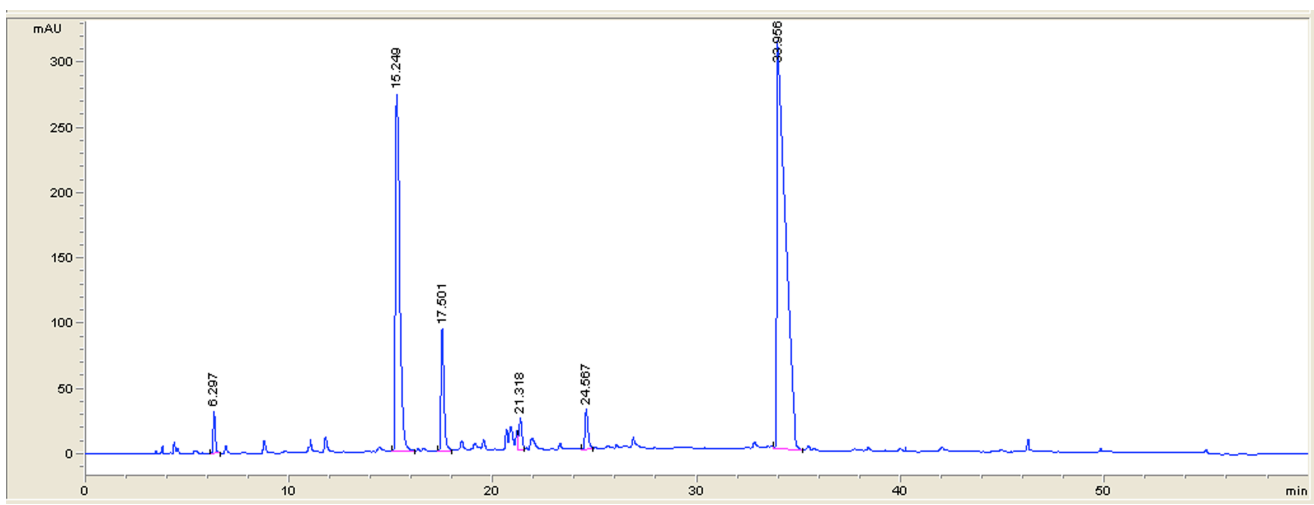

$7 b$

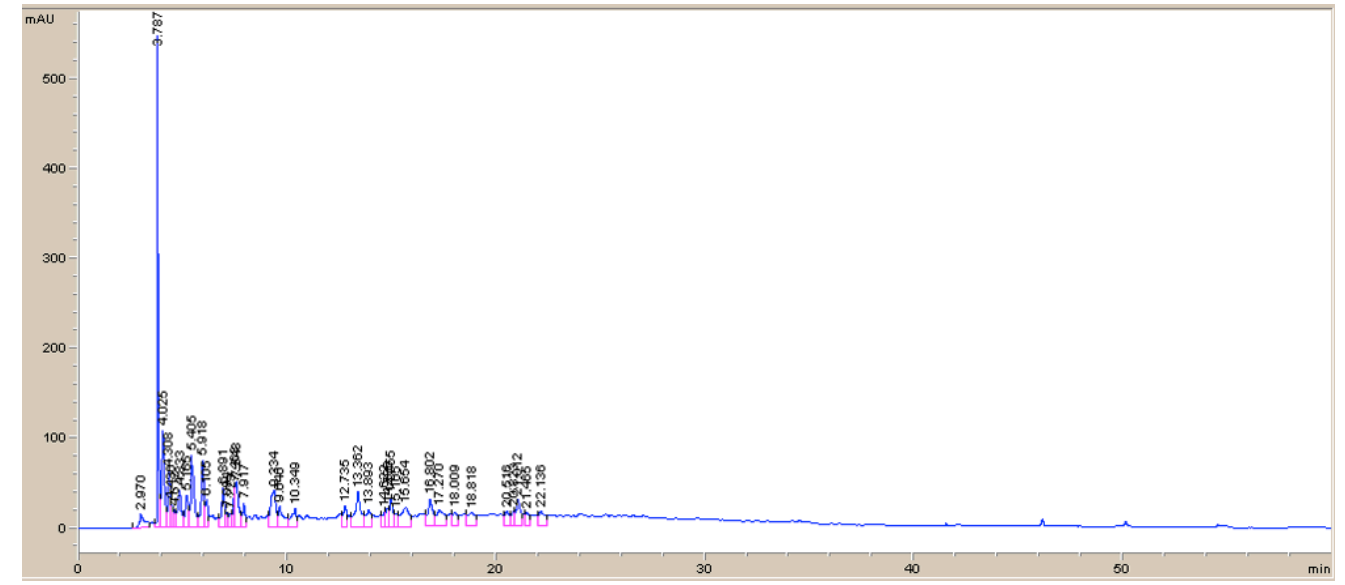

$7 c$

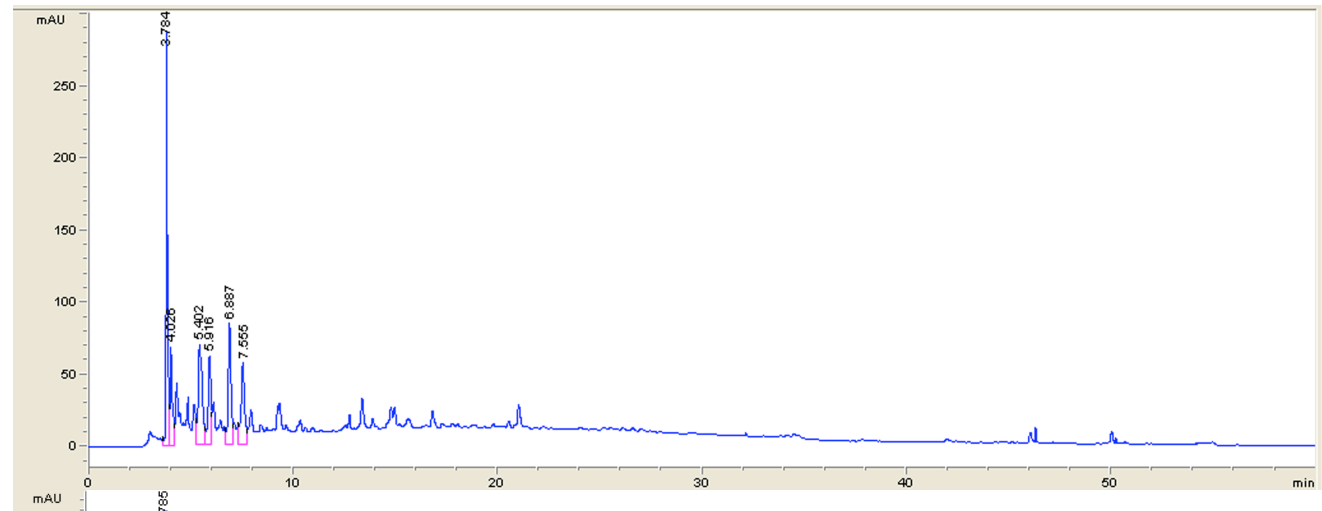

$7 d$

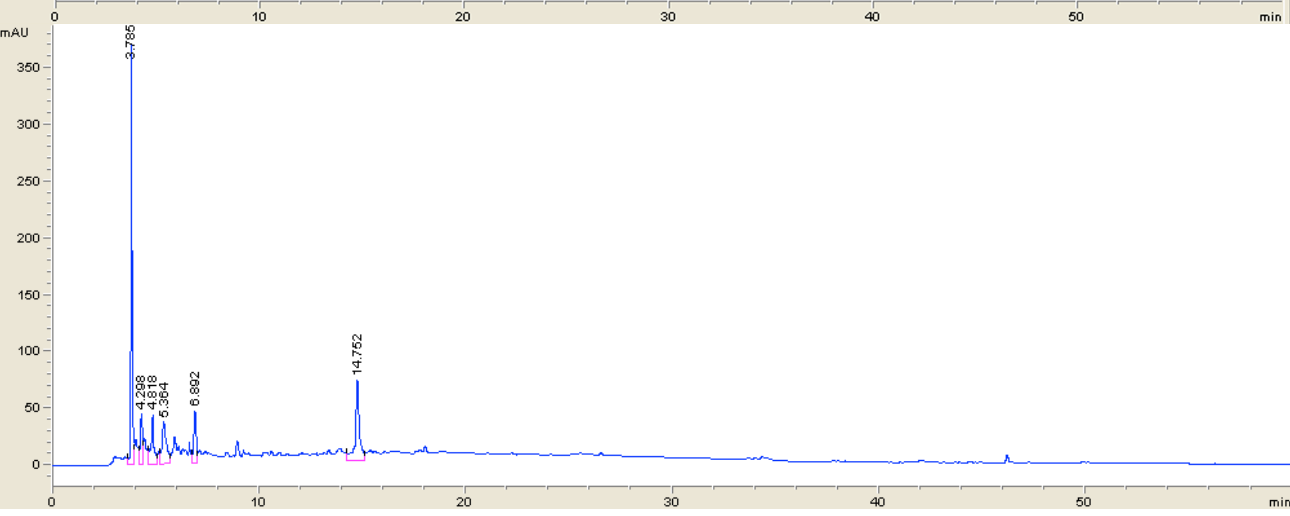

Figure 7: a) Reference dye Reactive Black 5 and Reactive Red 2, b) HPLC reservoir 1 080528, c) HPLC reservoir 2080528 , d) HPLC reservoir 3080528 


\section{CONCLUSIONS}

The fungus Bjerkandera strain BOL 13 was able to grow on sterile forest residues but had trouble competing with the microbial community inhabiting the forest residues. The microbial community on the other hand performed even better decolouration of the azo dyes used.

The transfer of microorganisms from forest residues was successful, and a community able to decolourize the azo dyes Reactive Black 5 and Reactive Red 2 was able to establish on the soft wood shavings.

A continuous system based on wood shavings and a consortium of microorganisms from forest residues is able to decolourize high concentrations of the two azo dyes Reactive Red 2 and Reactive Black 5 and mineralize most of the metabolites.

\section{ACKNOWLEDGEMENTS}

The Swedish International Development Cooperation Agency (SIDA) is gratefully acknowledged for financial support.

\section{REFERENCES}

[1] Alex R 2009 Characterization of dye decolourizing microorganisms from textile effluents in Dar es Salaam. In: Environmental Biotechnology, (Dar es Salaam: University of Dar es Salaam) p 100

[2] Chen H 2006 Recent advances in azo dye degrading enzyme research Current protein \& peptide science 7 101-11

[3] Chiavola A 2009 Textiles Water Environment Research 81 1696-730

[4] Christie R M 2007 Colour Chemistry: The Royal Society of Chemistry)

[5] Commission E 2003 Reference Document on Best Available Techniques for the Textiles Industry. Intergrated Pollution Prevention and Control (IPPC))

[6] Dow 2010 Dow Water \& Process Solutions, http://www.dow.com/liquidseps/.

[7] Koch 2010 Membrane systems, http://www.kochmembrane.com/sep uf.html

[8] Libra J A, Borchert M, Vigelahn L and Storm T 2004 Two stage biological treatment of a diazo reactive textile dye and the fate of the dye metabolites Chemosphere $\mathbf{5 6}$ 167-80

[9] Nilsson I, Moller A, Mattiasson B, Rubindamayugi M S T and Welander U 2006 Decolorization of synthetic and real textile wastewater by the use of white-rot fungi Enzyme and Microbial Technology 38 94-100

[10] O'Neill C, Lopez A, Esteves S, Hawkes F R, Hawkes D L and Wilcox S 2000 Azo-dye degradation in an anaerobic-aerobic treatment system operating on simulated textile effluent Applied Microbiology and Biotechnology 53 249-54

[11] O'Neill C O, Hawkes F, R. , Hawkes D, L. , Lourenço N, D., Pinheiro H, M. and Delée W 1999 Colour in textile effluents - sources, measurement, discharge consents and simulation: a review Journal of Chemical Technology \& Biotechnology 74 100918

[12] Shaul G M, Holdsworth T J, Dempsey C R and Dostal K A 1991 Fate of water soluble azo dyes in the activated sludge process Chemosphere 22 107-19

[13] Stolz A 2001 Basic and applied aspects in the microbial degradation of azo dyes Applied Microbiology and Biotechnology 56 69-80

[14] Van Der Zee F P, Bisschops I A E, Blanchard V G, Bouwman R H M, Lettinga G and Field J A 2003 The contribution of biotic and abiotic processes during azo dye reduction in anaerobic sludge Water Research 37 3098-109 
[15] van der Zee F P and Villaverde S 2005 Combined anaerobic-aerobic treatment of azo dyes - A short review of bioreactor studies Water Research 39 1425-40

[16] Watanabe K, Manefield M, Lee M and Kouzuma A 2009 Electron shuttles in biotechnology Current Opinion in Biotechnology 20 633-41 